ISSN 0258-7122 (Print), 2408-8293 (Online)

Bangladesh J. Agril. Res. 42(2): 363-371, June 2017

\title{
AGRO ECONOMIC PERFORMANCE OF BIO-SLURRY ON BORO RICE CULTIVATION IN SOME SITES OF MOULVIBAZAR DISTRICT
}

\author{
M. R. SHAHEB ${ }^{1}$, M. I. NAZRUL ${ }^{2}$ AND A. S. M. M. R. KHAN ${ }^{3}$
}

\begin{abstract}
Soil fertility in Bangladesh is gradually diminishing and this is now becoming a critical issue. Biogas slurry is a renewable energy produced organic fertilizer can be applied for maintaining the fertility of soil. In this study, a two years experiment was conducted in the year 2011 and 2012 at the farmer's field of Moulvibazar district under the agroecological zone 20 (AZE-20). The overall objective of the study was to observe the effect of bio-slurry on the agroeconomic performance of boro rice cultivation at on-farm condition. Three fertilizer treatments viz., $\mathrm{T}_{1}$ : Soil test based (STB) inorganic fertilizer for high yield goal (HYG), $\mathrm{T}_{2}$ : Integrated Plant Nutrient System (IPNS) based inorganic fertilizer + cowdung bio-slurry 5 tha $^{-1}$ for $\mathrm{HYG}$ and $\mathrm{T}_{3}$ : Farmer's practice as control i.e. average of 20 farmers fertilizer application dose in boro rice were considered during experimentation. Results revealed that bioslurry based boro rice production is more profitable than chemical fertilizer. The highest grain yield $\left(5.06 \mathrm{t} \mathrm{ha}^{-1}\right)$ was recorded from IPNS with $5 \mathrm{t} \mathrm{ha}^{-1}$ cow dung slurry for HYG $\left(\mathrm{T}_{2}\right)$ while the lowest yield was obtained from farmer's practice. However, yield increase due to application of $5 \mathrm{t} \mathrm{ha}^{-1}$ Cowdung slurry slurry with IPNS based inorganic fertilizer was 115 and $124 \%$ compared to STB inorganic fertilizer and farmers followed treatment. Gross margin (Tk.65900 ha ${ }^{-1}$ ), benefit cost ratio (2.59) and marginal rate of return (451) were also obtained higher in the same treatment. Thus, nutrient package NPKSZn@102-12-25-18-2 kg + cowdung slurry 5 tha $^{-1}$ might be helpful to get increased yield and improve soil health in AZE-20.
\end{abstract}

Keywords: Bio-slurry, IPNS, boro rice, profitability, soil health, AEZ-20.

\section{Introduction}

Soil fertility in Bangladesh is gradually diminishing and this is now becoming a critical issue. One of the reasons is over-use as well as prolonged use of chemical fertilizers in the soil. A good soil should have at least $2.0 \%$ organic matter (OM), but in Bangladesh most of the soils have less than 1.5\% OM and some soils have even less than 1\% OM (FRG, 2012). Sinha and Rahman (2005) stated that the organic matter content in a soil should be over $3 \%$, however it is now less than

${ }^{1} \mathrm{PhD}$ Scholar, Harper Adams University, UK and the University of Illinois at Urbana Champaign, IL 61801, USA, ${ }^{1 \& 2}$ Senior Scientific Officer, On-Farm Research Division, Bangladesh Agricultural Research Institute (BARI), Sylhet-3100, Bangladesh, ${ }^{3}$ Chief Scientific Officer, On-Farm Research Division, BARI, Gazipur-1701, Bangladesh. 
$1.5 \%$ in many places. Thus, recycling of organic matter is essential for maintaining soil fertility.

Bio-slurry produced from biogas plant rich in nutrients can be used successfully for crop production. It is an important type of organic manure that is applied in the form of semi liquid or compost. It contains considerable amount of plant nutrients than cowdung, poultry manure or even in compost that improves the soil fertility. It has no toxic or harmful effects, the nutrient quality of slurry is higher than that of compost manure and chemical fertilizer as the minimal loss of nitrogen in slurry is more effective as fertilizer than composted cattle dung (Islam, 2006; BCAS, 2009). Joshi et al. (1994) reported that use of bio-slurry along with inorganic fertilizers may be a good option for increasing soil fertility. Application of bio-slurry gave significantly higher yield in vegetables. The preliminary experimental results indicated that the yield of crops and vegetables could be increased from 10 to 30 percent through the application of slurry (FAO, 1996). Bio-slurry has proven to have positive effects on yields compared to not using any soil amendments and fertilizers. In comparison with other organic fertilizers such as FYM or compost, the content of readily available $\mathrm{N}$ for plants is higher after bio-slurry application (Groot and Bogdanski, 2013). Bonten et al. (2014) asserted that nutrients in bio-slurry, especially nitrogen, are more readily available than in manure, leading to a larger short term fertilization effect. Although Moller et al. (2008) found that the yields did not significantly differ between the different treatments (Bio-slurry, undigested liquid slurry and solid FYM) except for spring wheat, where the bio-slurry treatment led to higher yields due to immediate use of the readily available $\mathrm{NH}^{+}-\mathrm{N}$. However, other study suggested that rice yields increased by $23 \%$ compared to synthetic fertilizer application (Warnars and Oppenoorth, 2014). Application of slurry can increase both late and early rice yields to 44.3 and $31 \%$ while combined application with ammonium bicarbonate, the rice yields can increase to $12.1 \%$ (SNV, 2011). Batsai et al. (1979) observed that chemical fertilizer along with organic manure produced the highest cabbage yield. Boro rice is a major crop which contributes more than $50 \%$ of total rice production in Bangladesh. To achieve self-sufficiency in food grains production in a sustainable manner by improving the productivity on a short and medium term basis, sustainable intensification of rice along with non rice production are essential. Each year biogas plants are installing all over the Bangladesh by both the government as well as NGOs initiative. Their by-product 'bioslurry' is therefore needed to apply in the soil for helping sustainability of crop production and soil health management. Bio-slurry contains considerable amount of nutrients and the quality is higher than that of compost manure and chemical fertilizer. Thus, use of bio-slurry along with inorganic fertilizers may be a good option for increasing soil fertility in Bangladesh. Research work on the biogas slurry is lacking in acidic soil of Sylhet, Bangladesh. Therefore, the present study was undertaken to evaluate the efficiency of bio-slurry on the performance of boro rice 
crops with the objectives: to determine the effect of bio-slurry application on soil nutrient status, to find out the effect of bio-slurry use on the yield and yield attributes of boro rice, and to estimate the financial performance of bio-slurry in boro rice cultivation.

\section{Materials and Method}

The experiment was conducted at the farmer's field at multi location testing site, Moulavibazar under On Farm Research Division, Bangladesh Agricultural Research Institute, Sylhet in the year 2011 and 2012. The trial was laid out in a randomized complete block design with three replications. There were three fertilizer treatments viz. $\mathrm{T}_{1}$ : Soil test based (STB) inorganic fertilizer for high yield goal ( $\mathrm{HYG}), \mathrm{T}_{2}$ : Integrated Plant Nutrient System (IPNS) based inorganic fertilizer + cowdung bio-slurry 5 tha $^{-1}$ for HYG and $\mathrm{T}_{3}$ : Farmer's practice as control i.e. average of 20 farmers fertilizer application dose in boro rice. The initial soil nutrient status of the experimental soil and treatment wise nutrient elements are presented in Tables 1 and 2 . The plot size was $6 \mathrm{~m} \times 5 \mathrm{~m}$ the rice variety BRRI dhan 29 was used in the trial. Thirty days aged entire amount of cowdung slurry as per treatment were applied 4 days before final land preparation. The whole amount of PKSB and $1 / 3$ of $\mathrm{N}$ were applied during final land preparation. The rest of $\mathrm{N}$ was top dressed at 21 and 45 days after transplanting of boro rice. Twenty seven days old of boro rice seedling were transplanted on 15 March in both the years. Plant protection measures and other intercultural operations were done as and when necessary. The crop was harvested on 28 June 2011 and 30 June 2012. Data on yield and yield attributes viz., plant height, tiller per plant, panicle per $\mathrm{m}^{2}$ and 1000 grain weights were recorded in time. Individual plot wise data on grain and straw yield were recorded and converted into per hectare yield. Biological yield is expressed as the combined yield of grain and straw yields while the harvest index was calculated with the grain yield multiply with 100 and then divided by biological yield. The partial budget and marginal analysis of cost and return was done as per Perrin et al. (1979) and Karim and Elias (1992). The collected data were analyzed following the ANOVA technique with the help of MSTAT-C software. The mean differences among the treatment means were adjudged by Least Square Difference (LSD) test (Gomez and Gomez., 1984).

Table 1. Initial soil nutrient status of the experimental plot (average of 2011 and 2012)

\begin{tabular}{l|c|c|c|c|c|c|c}
\hline Elements & $\begin{array}{c}\mathrm{N} \\
(\%)\end{array}$ & $\begin{array}{c}\mathrm{P}(\mu \mathrm{g} / \mathrm{g} \\
\text { soil })\end{array}$ & $\begin{array}{c}\mathrm{K}(\mathrm{meq} . \\
/ 100 \mathrm{~g} \\
\text { soil })\end{array}$ & $\begin{array}{c}\mathrm{S}(\mu \mathrm{g} / \mathrm{g} \\
\text { soil })\end{array}$ & $\begin{array}{c}\mathrm{Zn}(\mu \mathrm{g} / \mathrm{g} \\
\text { soil })\end{array}$ & $\mathrm{OM}(\%)$ & $\mathrm{pH}$ \\
\hline Value & 0.11 & 3.00 & 0.08 & 7.50 & 0.07 & 1.95 & 4.5 \\
\hline Interpretation & Low & $\begin{array}{c}\text { Very } \\
\text { low }\end{array}$ & Low & $\begin{array}{c}\text { Very } \\
\text { low }\end{array}$ & Low & Moderate & $\begin{array}{c}\text { Very strongly } \\
\text { acidic }\end{array}$ \\
\hline
\end{tabular}


Table 2. Nutrient packages for boro rice cultivation

\begin{tabular}{l|l}
\hline Treatments & N-P-K-S-Zn $\left(\mathrm{kgha}^{-1}\right)$ \\
\hline $\mathrm{T}_{1}:$ STB inorganic fertilizer dose for HYG & $125-22-55-18-2$ \\
$\mathrm{~T}_{2}:$ IPNS basis inorganic fertilizer + & $102-12-25-18-2+5$ tha $^{-1}$ cow \\
cowdung slurry @ 5tha ${ }^{-1}$ for HYG & dung $(\mathrm{CD})$ slurry \\
$\mathrm{T}_{3}:$ Farmer's practice as control (average & $130-25-45-20-0$ \\
of 20 farmers fertilizer dose ) & \\
\hline
\end{tabular}

\section{Results and Discussion}

Two years results did not vary statistically, so pooled analyses were done. Results revealed that the yield attributes and yield of boro rice (BRRI dhan29) significantly influenced by different nutrient packages except 1000 grain weight and straw yield (Table 4). The detailed descriptions are furnished below:

\section{Effect of Bio-slurry Application on Soil Nutrients}

The post harvest soil test analysis revealed that there were increased in soil nutrients in bio-slurry applied experimental plot $\left(\mathrm{T}_{2}\right.$ : CD slurry @ $5 \mathrm{t} \mathrm{ha}^{-1}$ along with IPNS based inorganic fertilizer) compared to initial soil nutrient status and other treatments where bio-slurry were not incorporated $\left(T_{1}\right.$ and $\left.T_{3}\right)$. However, higher doses of fertilizer in farmer's practice slightly deteriorates some of the soil nutrients that might affect on the fertility of the soil. Soil $\mathrm{pH}$ was also increased in the bio-slurry treated plot in comparison to others (Table 3). Kumer et al. (2015) reported that biogas slurry provides huge nutrient potential for vegetative and reproductive growth of field crops with long term sustainability and help in reducing fertilizer demand and provide an eco-friendly way of maintaining productivity and soil health.

Table 3. Soil nutrient status after harvest of boro rice (average of 2011 and 2012)

\begin{tabular}{c|c|c|c|c|c|c|c}
\hline Treatment & $\begin{array}{c}\mathrm{N} \\
(\%)\end{array}$ & $\begin{array}{c}\mathrm{P}(\mu \mathrm{g} / \mathrm{g} \\
\text { soil })\end{array}$ & $\begin{array}{c}\mathrm{K}(\mathrm{meq} . \\
/ 100 \mathrm{~g} \\
\text { soil) }\end{array}$ & $\begin{array}{c}\mathrm{S}(\mu \mathrm{g} / \mathrm{g} \\
\text { soil })\end{array}$ & $\begin{array}{c}\mathrm{Zn}(\mu \mathrm{g} / \mathrm{g} \\
\text { soil })\end{array}$ & $\mathrm{OM}(\%)$ & $\mathrm{pH}$ \\
\hline $\begin{array}{c}\text { Initial } \\
\text { status }\end{array}$ & 0.11 & 3.00 & 0.08 & 7.50 & 0.07 & 1.90 & 4.50 \\
$\mathrm{~T}_{1}$ & 0.12 & 3.50 & 0.09 & 8.00 & 0.08 & 1.92 & 4.53 \\
$\mathrm{~T}_{2}$ & 0.15 & 4.12 & 0.11 & 9.24 & 0.10 & 1.98 & 4.65 \\
$\mathrm{~T}_{3}$ & 0.10 & 3.00 & 0.07 & 7.40 & 0.078 & 1.85 & 4.48 \\
\hline
\end{tabular}

$\mathrm{T}_{1}$ : STB inorganic fertilizer dose for $\mathrm{HYG}_{2} \mathrm{~T}_{2}$ : IPNS basis inorganic fertilizer + CD bioslurry @5 tha ${ }^{-1}$ for HYG and $\mathrm{T}_{3}$ : Farmer's practice (Control) 


\section{Effect of Bioslurry Application on Yield attributes}

Plant height: Application of fertilizers following IPNS approach gave the longest plant height of boro rice compared to the use of only inorganic fertilizers. The highest plant height $(103.91 \mathrm{~cm})$ was obtained from CD slurry @ $5 \mathrm{t} \mathrm{ha}^{-1}$ with IPNS based inorganic fertilizer $\left(\mathrm{T}_{2}\right)$ which was statistically similar to soil test based inorganic fertilizer treatment $\left(\mathrm{T}_{3}\right)(101.27 \mathrm{~cm})$. The lowest plant height $(98.89 \mathrm{~cm})$ was obtained from farmer's practices treatment $\left(\mathrm{T}_{3}\right)$ (Table 4$)$.

Tiller per plant: Like plant height, the highest number of tillers per plant (12.33) was obtained from $\mathrm{T}_{2}$ treatment (CD slurry @ $5 \mathrm{t} \mathrm{ha}^{-1}$ with IPNS based inorganic fertilizer) which was close to $T_{3}$ treatment. However, although the result was identical with $T_{3}$ and $T_{1}$, the lowest tiller per plant was observed in $T_{1}$ treatment (Table 4).

Panicle per $\mathbf{~ m}^{2}$ : The highest number of panicles per $\mathrm{m}^{2}$ (361) was obtained from $\mathrm{T}_{2}$ treatment which was followed by $\mathrm{T}_{3}$ treatment. The lowest panicle per $\mathrm{m}^{2}$ (297) was recorded in soil test based inorganic fertilizer $\left(T_{1}\right)$ treatment (Table 4).

1000 grain weight: 1000 grain weight of boro rice was not influenced by the different nutrient packages. It might be due to the genetical character of the variety that did not show any difference in 1000 grain weight of boro rice. However, the highest 1000 grain weight $(22.59 \mathrm{~g})$ was obtained from $\mathrm{T}_{2}$ treatment which was statistically similar to $T_{1}$ treatment. The lowest 1000 grain weight $(21.22 \mathrm{~g})$ was recorded in inorganic fertilizer followed by farmers practice (Table 4).

\section{Effect of Bioslurry Application on Boro rice Yield}

Table 4 showed that the highest grain yield $\left(5.06 \mathrm{t} \mathrm{ha}^{-1}\right)$ was obtained from IPNS with $5 \mathrm{t} \mathrm{ha}^{-1}$ cowdung slurry for $\mathrm{HYG}\left(\mathrm{T}_{2}\right)$, while the lowest yield was obtained from farmer's practice $\left(\mathrm{T}_{3}\right)$. From this result, it might be evident that cowdung slurry has a great potentiality in increasing boro rice yield. However, yield increase due to application of CD slurry @ $5 \mathrm{t} \mathrm{ha}^{-1}$ with IPNS based inorganic fertilizer $\left(\mathrm{T}_{2}\right)$ was 115 and $124 \%$ compared to soil test based inorganic fertilizer $\left(\mathrm{T}_{1}\right)$ and farmers followed treatments $\left(\mathrm{T}_{3}\right)$. Results revealed that straw yield of boro rice was non significant among the nutrient management packages. However, the highest straw yield $\left(6.40 \mathrm{t} \mathrm{ha}^{-1}\right)$ was obtained from $\mathrm{T}_{3}$ treatment, while the lowest straw yield was found in STB inorganic fertilizer package $\left(\mathrm{T}_{1}\right)$ treatment. Gnanamani and Kasturi Bai (1992) reported that the yield of rice grain showed a $23 \%$ increase when soil was amended with B, compared to SF (containing N, K and P). Similar results were also observed by Bharde (2003). A combination of biogas slurry @ 12.5 tha $^{-1}$ and $100 \%$ NPK had pronounced effect on enhanced growth, yield attributes and yield of rice (Gurung, 1997). The results are also in conformity with the findings of Shaheb and Nazrul (2011) who 
reported that inorganic fertilizer along with cowdung slurry @ $5 \mathrm{t} \mathrm{ha}^{-1}$ in IPNS approach produced the highest yield of cabbage.

Table 4. Effect of bio-slurry on yield and yield attributes of boro rice (var. BRRIdhan29) (pooled of 2011 and 2012)

\begin{tabular}{c|c|c|c|c|c|c|c|c}
\hline Treatment & $\begin{array}{c}\text { Plant } \\
\text { height } \\
(\mathrm{cm})\end{array}$ & $\begin{array}{c}\text { Tiller } \\
\text { plant } \\
(\text { nos. })\end{array}$ & $\begin{array}{c}\text { Panicle } \\
\mathrm{m}^{-2} \\
(\text { nos. })\end{array}$ & $\begin{array}{c}1000 \\
\text { grain } \\
\text { weight } \\
(\mathrm{g})\end{array}$ & $\begin{array}{c}\text { Grain } \\
\text { yield } \\
\left(\text { tha }^{-1}\right)\end{array}$ & $\begin{array}{c}\text { Straw } \\
\text { yield } \\
\left(\text { tha }^{-1}\right)\end{array}$ & $\begin{array}{c}\text { Harvest } \\
\text { Index }\end{array}$ & $\begin{array}{c}\text { Biological } \\
\text { yield } \\
\left(\text { tha }^{-1}\right)\end{array}$ \\
\hline $\mathrm{T}_{1}$ & $101.27 \mathrm{~b}$ & $10.00 \mathrm{~b}$ & $296.67 \mathrm{c}$ & 21.55 & $4.37 \mathrm{~b}$ & 5.83 & 43 & 10.13 \\
$\mathrm{~T}_{2}$ & $103.91 \mathrm{a}$ & $12.33 \mathrm{a}$ & $361.33 \mathrm{a}$ & 22.59 & $5.06 \mathrm{a}$ & 6.27 & 45 & 11.33 \\
$\mathrm{~T}_{3}$ & $98.89 \mathrm{~b}$ & $10.67 \mathrm{~b}$ & $321.00 \mathrm{~b}$ & 21.22 & $4.07 \mathrm{~b}$ & 6.40 & 39 & 10.47 \\
\hline $\mathrm{LSD}_{0.05}$ & 2.53 & 1.31 & 17.41 & $\mathrm{NS}$ & 0.51 & $\mathrm{NS}$ & - & \\
$\mathrm{CV}(\%)$ & 1.10 & 5.25 & 5.06 & 2.34 & 5.00 & 7.37 & - & \\
\hline
\end{tabular}

$\mathrm{T}_{1}$ : STB inorganic fertilizer dose for HYG, $\mathrm{T}_{2}$ : IPNS basis inorganic fertilizer + CD bioslurry @5 tha ${ }^{-1}$ for HYG and $\mathrm{T}_{3}$ : Farmer's practice (Control).

Higher crop yields due to application of bio-slurry were also reported by Jayakumar et al. (1993), Manna and Hazra (1996) and Galli and Lalitpur (2001). Biogas slurry increases agricultural production because of its higher content of plant nutrients, growth hormones and enzymes (FAO, 1996). Garfi et al. (2011) asserted that the potato yield was increased by $27.5 \%$ with bioslurry compared to the control.

\section{Profitability of Boro rice cultivation}

The cost and return analysis of different fertilizer treatments are presented in Table 5. The highest gross return (Tk.107470 ha-1) and gross margin (Tk.65900 $\mathrm{ha}^{-1}$ ) were obtained from $\mathrm{T}_{2}$ (CD slurry @ $5 \mathrm{t} \mathrm{ha}^{-1}$ with IPNS based inorganic fertilizer for $\mathrm{HYG}$ ). The variable cost was also higher in $\mathrm{T}_{2}$ because of additional use of cowdung bio-slurry. Karim and Elias (1992) pointed that the farmers always try to maximize their return up to the point where returns to investment are the highest as the capital is scarce. The purpose of marginal analysis is to reveal how the gross margin from investment increase as the amount of investment decreases (Perrin et. al. 1989). The highest BCR (2.59) and marginal rate of return (451) were recorded in $\mathrm{T}_{2}$ (CD slurry @ $5 \mathrm{t} \mathrm{ha}^{-1}$ with IPNS based inorganic fertilizer for $\mathrm{HYG}$ ). It indicates that if a farmer spends additional one hundred taka, he can get an extra income of Tk. 451. Financially profitable production of cabbage and cauliflower were also found from poultry manure slurry@3 t ha-1 or CD slurry@ $5 \mathrm{t} \mathrm{ha}^{-1}$ with IPNS basis inorganic fertilizer in AEZ-28 (BARI, 2008). The results are also in conformity with the findings of Shaheb and Nazrul (2011). Thus, nutrient package NPKSZn @102-12-25-18-2 $\mathrm{kgha}^{-1}+$ cow dung slurry $5 \mathrm{tha}^{-1}$ might be helpful to get higher yield of boro rice in agroecological zone 20 (AZE-20). 
Table 5. Cost and return analysis of the effect of bio-slurry application on Boro rice (var. BRRI dhan 29) (average of 2011 and 2012)

\begin{tabular}{c|c|c|c|c|c}
\hline Treatment & $\begin{array}{c}\text { Gross Return } \\
\left(\mathrm{Tk}^{-h^{-1}}\right)\end{array}$ & $\begin{array}{c}\text { Total variable } \\
\text { cost (TVC) } \\
\left(\text { Tk.ha }^{-1}\right)\end{array}$ & $\begin{array}{c}\text { Gross } \\
\text { margin } \\
\left(\text { Tk.ha }^{-1}\right)\end{array}$ & $\begin{array}{c}\text { BCR } \\
\text { On TVC }\end{array}$ & MRR (\%) \\
\hline 1 & 2 & 3 & $4(2-3)$ & $5(2 \div 3)$ & 6 \\
\hline $\mathrm{T}_{1}$ & 93230 & 39320 & 53910 & 2.37 & 257 \\
$\mathrm{~T}_{2}$ & 107470 & 41570 & 65900 & 2.59 & 451 \\
$\mathrm{~T}_{3}$ & 87800 & 37205 & 50595 & 2.36 & - \\
\hline
\end{tabular}

$\mathrm{T}_{1}$ : STB inorganic fertilizer dose for $\mathrm{HYG}, \mathrm{T}_{2}$ : IPNS basis inorganic fertilizer $+\mathrm{CD}$ bioslurry@5 tha ${ }^{-1}$ for HYG and $\mathrm{T}_{3}$ : Farmers practice (Control)

N. B. Price of inputs and outputs ((Tk. $\left.\mathrm{Kg}^{-1}\right)$ : Urea-12, TSP-22, MoP-15, Gypsum-10, Zinc sulphate-130, CD slurry-1, Rice seed-33, Rice grain-20, and Rice straw-1.

\section{Conclusion}

From the findings of the study it revealed that bio-slurry based boro rice production is more profitable than chemical fertilizer. The highest grain yield (5.06 $\mathrm{t} \mathrm{ha}^{-1}$ ) was recorded from IPNS with $5 \mathrm{t} \mathrm{ha}^{-1}$ cow dung slurry for HYG while the lowest yield was obtained from farmer's practice. Yield increase due to application of CD slurry @ $5 \mathrm{t} \mathrm{ha}^{-1}$ with IPNS based inorganic fertilizer for HYG was 115 and $124 \%$ compared to STB inorganic fertilizer and farmers treatments. According to partial budget and marginal analysis, the same treatment provided the highest gross return (Tk.107470 ha' ${ }^{-1}$ ) and gross margin (Tk.65900 ha- ${ }^{-1}$. BCR (2.59) and marginal rate of return (451) were also recorded higher in CD slurry @ $5 \mathrm{t} \mathrm{ha}^{-1}$ with IPNS based inorganic fertilizer for HYG. Farmers were found to be highly impressed to receive higher yield of rice using cow dung slurry and they wanted to apply bio-slurry in their field in future for receiving sustainable crop production. Thus, it might be recommended that CD bioslurry @ $5 \mathrm{t} \mathrm{ha}^{-1}$ along with inorganic fertilizer in IPNS approach could be applied for boro rice cultivation in Moulvibazar. It would be benefited for farmers to contribute more in food security as well as sustainable crop and soil management. Hence, it is also strongly recommended to continue this trial in other field crops including horticultural crops as a regular basis by the concerned organizations covering all agro-ecological zones of Bangladesh.

\section{Acknowledgement}

The authors are highly acknowledged to respected authority as the research work was accomplished with the financial support of NDBMP, IDCOL/SNV. 


\section{References}

BARI. 2008. Project report on "Bio-slurry management and its effect on soil fertility and crop production". Soil Science Division \& On-Farm Research Division, Bangladesh Agricultural Research Institute, Gazipur 1701, Bangladesh. Pp. 41.

Batsai, S. T., A. A. Polyakev and R. F. Nedbal. 1979. Effect of organic and mineral fertilizers on the yield and quality of irrigated late and white cabbage in the steppe region of the Crimea. Hort. Abst. 49(11): 730.

BCAS. 2009. Biogas user survey 2008 under national domestic Biogas and manure Program (Final report). IDCOL, Dhaka.

Bharde, N. M., Y. S. Shivay and S. Singh. 2003. Effect of bioslurry and neem oil-treated urea sources in rice (Oryza sativa)-wheat (Triticum aestivum) cropping system. Indian J. Agron. 48(2): 73-75.

Bonten, L.T. C., K. B. Zwart., R. P. J. J. Rietra1., R. Postma and M. J. G. de Haas. 2014. Bio-slurry as fertilizer. Is bio-slurry from household digesters a better fertilizer than manure? A literature review. Alterra report 2519. Alterra Wageningen UR, Wageningen, Pp. 50. www.wageningenUR.nl/en/alterra.

FAO. 1996. Biogas Technology: A Training Manual for Extension. Published by FAO. Rome, Italy.

FRG. 2012. Fertilizer Recommendation Guide, Bangladesh Agricultural Research Council (BARC), Farmgate, Dhake. p. 58.

Galli, K. and P. Lalitpur. 2001. Response to bio-slurry application on maize and cabbage in Lalitpur District, Nepal. Final Report. October 2001. GPO Box 1309, Kathmandu, Nepal. Pp. 63.

Garfi, M., P. Gelman., J. Comas., W. Carrasco., I. Ferrer. 2011. Agricultural reuse of the digestate from low-cost tubular digesters in rural Andean communities. Waste Management. doi:10.1016/j.wasman.2011.08.007.

Gnanamani, A. and R. Kasturi Bai. 1992. Influence of biodigested slurry on rice-gram cultivation. Bioresource Technol. 41(3):217-221.

Gomez, K. A and A.A. Gomez. 1984. Statistical procedures for Agricultural Research. $2^{\text {nd }}$ edn. John Wiley and Sons. New York. Pp. 207-215.

Groot, L. and A. Bogdanski. 2013. Bioslurry = Brown Gold? A review of scientific literature on the co-product of biogas production. Environment and Natural Resources working paper. FAO, Rome, Italy. www.fao.org. P. 1-45.

Gurung, J. B. 1997. Review of Literature on Effects of Slurry Use on Crop production. FINAL REPORT submitted to The Biogas Support Program Post Box 1966 Kathmandu, Nepal. Pp. 109.

Islam, M. S. 2006. Use of bioslurry as organic fertilizer in Bangladesh agriculture. Paper presented in the International Workshop, Bangkok, Thailand, 27-28, September 2006.

Jaykumar, M., M. Eyini and R. Elanogovan. 1993. Effect of biogass slurry on salanityinduced changes in growth and yield of sunflower. Indian J. Agril. Sci. 63(10): 655-657. 
Joshi, J. R., J. F. Moncrief, J. B. Swan and G. L. Malzer. 1994. Soil Till. Res. 31: 225.

Karim, M. R and S. M. Elias. 1992. Application of partial budget technique of fertilizer response data on T. aman and mustard. Bangladesh J. Agril. Res. 17(1): 24-28.

Kumar, S., L. C. Malav, M. K. Malav and S. A. Khan. 2015. Biogas Slurry: Source of Nutrients for Eco-friendly Agriculture. International J. Ext. Res. 2:42-46.

Manna, M. C and J. N. Hazra. 1996. Comparative performance of cowdung slurry, microbial inoculum and inorganic fertilizers on Maize. J. Indian Soc. of Soil Sci. 44: 526-528.

Moller, K., W. Stinner, A. Deuker and G. Leithold. 2008. Effects of different manuring systems with and without biogas digestion on nitrogen cycle and crop yield in mixed organic dairy farming systems. Nutrient Cycling in Agroecosystems. 82: 209-232.

Perrin, R. K., D. L. Winkelman, E. R. Moseardi and J. R. Anderson. 1979. Farm agronomic data on farmer's recommendations. Information Bulletin 27, CIMMYT. Mexico.

Shaheb, M. R. and M. I. Nazrul. 2011. Performance of cabbage under IPNS with cowdung bio-slurry in estern Surma-Kushiyara floodplain. Bangladesh Agron. J. 14(1\&2): 23-26.

Sinha M. H. and M. M Rahaman. 2005. Environmental management practice of poultry waste. Bangladesh poultry sector development project, 2005.

SNV. 2011. Technology and Mass- Dissemination Experiences from Asia. Biogas compact course PPRE- Oldenburg University. April 26-28, 2011.

Warnars, L. and H. Oppenoorth, 2014. Bioslurry: a supreme fertilizer. A study on bioslurry results and uses. https:/www.hivos.org/sites/default/files/bioslurry_ book.pdf . P.25-26 (Last accessed on 7 July, 2015). 
